\title{
$\overline{\text { A CAMPANHA DE CARLOS FUENTES }}$
}

\section{Igor Carneiro Leão Zanoni ${ }^{1}$}

Carlos Fuentes não tem a exuberância amazônica de Garcia Márquez, nem o rigor barroco de Carpentier. Entretanto, é um autor como pouquíssimos. Tomemos como exemplo A campanha (1990, versão brasileira da Rocco, de 1996). Na superfície, a trama é conduzida pela vida venturosa de Baltasar Bustos que, de orador apaixonado por Rousseau nos cafés de Buenos Aires à época das guerras de independência, como heróico e contraditório romântico, ama a esposa do marquês de Cabral, Ofélia Salamanca, e no incêndio movido pela plebe contra o Tribunal do Vice-Reinado do Rio da Prata, salva o filho da amada, trocando-o por um bebê negro que morre no episódio.

A partir daí, sua metamorfose expressa-se em sua própria figura corpórea: de obeso, míope e claro, emagrece, tornando-se um guerreiro curtido ao lado dos principais articuladores da libertação de Espanha. Abandona, após a morte do pai, no pampa, a irmã, viaja por todas as possessões castelhanas, unindo-se, na travessia dos andes, a San-Martine, ao atacar o Chile, perde-se na diplomacia dos boatos em Maracaibo, luta com os montoneros de Miguel Lanza no Alto Peru e termina no México, no acampamento do padre Anselmo Quintana.

A aventura termina com Bustos recobrando seus antigos amigos de juventude em Buenos Aires, adotando como sua a criança que salvara, após descobrir que sua amada espanhola era uma contra-espiã, lutando ao lado dos próceres a partir do alto cargo de seu marido. Ofélia morre, mas Baltazar termina sua lide junto ao filho adotivo e a Gabriela Cóos, jovem e sedutora atriz que conhecera no Chile.

É um happy end. Na contramão, entretanto, há o entrelaçar-se dessa América que surge na tensão entre liberdade voltairiana e igualdade rousseauniana. $\mathrm{O}$ estado da natureza em que vivem os índios não lhes ga-

${ }^{1}$ Professor do Departamento de Economia e do Programa de Pós-Graduação em Desenvolvimento Econômico da Universidade Federal do Paraná (PPGDE-UFPR). 
rante nada na ordem em gestação: seu lugar é por isso no máximo ao lado de chefetes locais, buscando republiquetas indígenas em páramos inviáveis. Por isso Bustos havia condenado uma criança negra: não havia destino para ela. Por isso mata em combate um índio que, não obstante, sente como um desejado e impossível irmão.

A idéia central do livro vem numa conversa, no México, entre o padre Quintana e Baltazar Bustos. Diz o padre:

Queremos agora ser europeus, ricos, governados pelo espírito das leis e dos direitos universais do homem? Pois eu te digo que nada será possível se não cuidarmos do cadaverzinho do nosso passado. O que eu estou pedindo é que não sacrifiquemos nada, meu filho, nem a magia dos índios, nem a teologia dos cristãos, nem a razão dos europeus contemporâneos: melhor ainda, resgatemos tudo o que somos para continuarmos sendo e sermos finalmente algo melhor.

Apesar desse pluralismo cultural, a matriz católica (mas específica):

... para mim Jesus disse: Anselmo, meu filho, não sejas um cristão acomodado, inferniza a vida da Igreja e do rei, eles adoram os católicos tranqüilos. Eu, por meu lado, adoro os cristãos revoltados, como tu: não ganhas nada sendo um católico sem problemas, um simples fiel, um homem de fé que nem sequer percebe que a fé é absurda e por isso é fé e não razão; a razão não pode ser ilógica, a fé tem de ser ilógica porque é preciso crer em Deus contra toda a evidência, e, se Eu fosse lógico, não seria Deus, não me teria sacrificado, teria aceito todas as tentações do Deserto e seria - estás Me ouvindo, filho Anselmo, estás me ouvindo, irmão Baltazar? - seria o mesmíssimo Diabo rabudo e mandinguento que inventou a frase "penso, logo existo...". Quanta pretensão! Nem o meu pensamento é meu, nem a minha existência. Nem penso nem existo sozinho. Compartilho cada palavra, com Deus, contigo, Baltazar, e também cada batida do coração.

Talvez nas linhas acima o leitor encontre motivos contemporâneos e eternos para retirar da estante um livro já esquecido de Carlos Fuentes. 